УДК373.2.035:371.4

DOI: $10.35619 /$ iiu.v1i10.171

\author{
Сськова Тетяна \\ кандидат педагогічних наук, доцент, \\ доцент кафедри дошкільної освіти \\ Бердянського державного педагогічного університету, \\ м. Бердянськ, Україна \\ ORCID: 0000-0003-4666-6871, \\ e-mail: tani4kaeskova@gmail.com
}

\title{
ТВОРЧА РЕАЛІЗАЦІЯ ІДЕЙ С. РУСОВОЇ У ПРОЦЕСІ ВИКОРИСТАННЯ РУЧНОЇ ПРАЦІ В РОБОТІ ЗАКЛАДІВ ДОШКІЛЬНОЇ ОСВІТИ
}

Анотація. Докорінна перебудова освіти в Україні спонукає вчених до розробки перспективних теоретичних і методичних моделей трудового виховання дошкільників 3 урахуванням досягнень педагогічної теорії та практики попередніх років. У цих умовах історичний досвід розвитку проблеми використання ручної праці у вихованні дітей дошкільного віку, i, зокрема, педагогічна спадщина Софії Русової має надзвичайно важливе значення. У статті висвітлюється педагогічна спадщина С. Русової щодо творчого використання ручної праці у вихованні дітей дошкільного віку, аналізуються іiї погляди, акцентується увага на використанні ручної праці в освітньому процесі дошкільних установ. У методичних працях С. Русової вказується, що одним із важливих чинників виховання в дошкільному віці $є$ ручна праця, яка впливає на різнобічний розвиток особистості. Саме завдяки їй формуються такі важливі якості особистості, як працелюбність, акуратність, ініціативність, творчість, товариська взаємодопомога, воля та багато інших, які стають основою людського життя. Педагог наголошувала, що починати трудове виховання слід у сім’і, оскільки саме в ній дитина отримує перші трудові вміння та навички. С Русова вважала, що зміст дитячої праці повинен відповідати не лише віковим та індивідуальним особливостям дитини, але й порі року. Визначний педагог акцентувала увагу на необхідності поєднання навчання 3 практичною діяльністю і зазначала, що постійно розвиваючи руку, яка $\epsilon$ одним 3 найкращих інструментів для висловлювання думки і яка дає змогу дитині якнайкраще розуміти весь матеріальний світ, ми надаємо дитині можливість міцніше засвоїти нову інформацію. На думку автора пропонованого дослідження, ідеї використання ручної праці, які були висвітлені у працях С. Русової, мали важливе значення для створення програмно-методичних документів, організації освітнього процесу у подальші періоди розвитку національної системи дошкільної освіти, та можуть бути творчо використані вихователями в роботі сучасних закладів дошкільної освіти для розробки ефективних виховних технологій.

Ключові слова: ручна праця, трудове виховання, працелюбність, заняття з ручної праці.

Постановка проблеми. Докорінна перебудова освіти в Україні на етапі розвитку сучасного суспільства, спонукає вчених до розробки перспективних теоретичних і методичних моделей трудового виховання дошкільників з урахуванням досягнень педагогічної теорії та практики попередніх років. У цих умовах історичний досвід використання ручної праці у вихованні дітей дошкільного віку, i, зокрема, педагогічна спадщина Софії Русової має надзвичайно важливе значення та може бути творчо використана у роботі сучасних закладів дошкільної освіти для розробки ефективних виховних технологій.

Аналіз останніх досліджень 3 проблеми. Як свідчить аналіз історикопедагогічних досліджень, питання історії національного дошкілля відображено в 
дисертаціях i наукових розвідках Л. Артемової, А. Богуш, Є. Коваленко, М. Мельничук, 3. Нагачевської, М. Стельмаховича, І. Улюкаєвої та ін. До проблеми вивчення педагогічного доробку Софії Федорівни Русової звертались такі науковці: I. Зайченко, Н. Калініченко, Є. Коваленко, Н. Малиновська, П. Пантюк, О. Проскурою, О. Сухомлинська та ін. Вони наголошували на тому, що її погляди є цілком сучасними в умовах сьогодення, у тому числі і ті, що стосуються питань творчого використання ручної праці в роботі закладів дошкільної освіти. У сучасних психолого-педагогічних дослідженнях проблема трудового виховання розглядається як виховання потреби та позитивного ставлення до трудової діяльності, формування працелюбності як базової якості особистості та відповідних трудових вмінь і навичок, що забезпечують успішність діяльності (В. Логінова, 3. Борисова, Р. Буре, Г. Бєлєнька, М. Машовець, Н. Кривошея та ін.).

Мета статті полягає в тому, щоб репрезентувати результати аналізу творчого доробку Софії Русової щодо ручної праці та показати можливості його використання в освітньому процесі сучасних закладів дошкільної освіти.

Виклад основного матеріалу дослідження. Перші дитячі садки почали з'являтися в Україні в кінці XIX ст. і активно поширювалися в першій третині XX ст. У народних дитячих садках трудовій діяльності відводилось важливе місце. Особливу увагу у вихованні педагоги надавали ручній праці і організовували спеціальні заняття, які супроводжувались бесідами або розповідями вихователя. Такі заняття впливали на розумовий розвиток, творчість, розвивали спритність рук, окомір і сприяли вихованню таких важливих рис особистості, як потреба у діяльності, активність, вміння доводити справу до кінця, працювати сумлінно, що впливало на формування працелюбності і підготовку дитини до подальшого трудового життя.

Сучасна педагогічна наука пов'язує становлення та розвиток дошкільної освіти 3 ім'ям Софії Русової, яка була фундатором українського дошкілля. В ії педагогічній системі неабияку роль відігравали і питання використання ручної праці у вихованні дітей. Аналіз педагогічної спадщини С. Русової дозволяє з'ясувати, що її педагогічні погляди щодо проблеми трудового виховання та використання ручної праці у освітньому процесі дитячого закладу, глибоко розкриті у працях «Теорія і практика дошкільного виховання», «Дошкільне виховання», «У дитячому садку», «Нова школа соціального виховання», «Сдина діяльна (трудова) школа» та інші. Софія Федорівна наголошувала на тому, що праця має велике соціальне значення для виховання; тому треба до неї залучати дітей з раннього дитинства, обов'язково враховуючи вікові особливості малюків: «Щоб дати дітям сучасне соціальне виховання, ми мусимо, перш за все, виховувати в дитині нахил до праці, звичку вважати працю як перший обов'язок, і для цього давати спочатку лише приємну працю, далі утворити такий сильний настрій серед дітей, завдяки якому кожна, навіть тяжка праця проводитиметься залюбки, весело» (Русова, 1997, с.167).

С. Русова зазначала, що праця - це основа виховання, яка мусить збудити в дитячій душі найбільше самостійної творчості, дати вільно розвиватися індивідуальності дитини і наголошувала: «Праця в сучасному вихованні $є$ метод, яким кожне знання зафіксовується в дитячій свідомості тим, що воно здобувається дитячою рукою: через руку в розум»(Русова, 1993, с.83).

У методичних працях Софії Федорівни вказується, що одним із важливих чинників трудового виховання в дошкільному віці $є$ ручна праця, яка впливає на різнобічний розвиток особистості. Саме завдяки їй формуються такі важливі якості особистості, як працелюбність, акуратність, ініціативність, творчість, товариська взаємодопомога, воля та багато інших, які стають основою людського життя.

На основі грунтовного аналізу наукових праць Софії Русової можна сказати, що вона поділяла ручну працю на такі види: загальнокорисна (господарська) - прибирання приміщення дитячого садка, догляд за рослинами та тваринами, прання лялькової білизни та невеличких речей, сервіровка столу тощо; естетично-декоративна - 
малювання, ліплення, аплікація, складання 3 паперу, вишивання на тонкому картоні й тканині, плетіння 3 кольорових паперових смужок та тканини, дрібні картонажі, виготовлення витинанок, виробів з природного та непридатного матеріалів, ляльковий та тіньовий театри, ткання на маленьких ткацьких верстатах тощо; навчальна праця, пов'язана з засвоєнням нових знань, вмінь та навичок; особливий вид ручної праці хліборобство (Русова, 1997, с. 254).

Педагог вважала, що зміст дитячої праці повинен відповідати не лише віковим та індивідуальним особливостям дитини, але й порі року. Для кожного сезону дослідниця пропонувала зміст праці і надавала конкретні методичні поради. Наприклад, вона рекомендувала в літню пору переносити всю роботу з дітьми ближче до природи: водити дітей на екскурсії до лісу, на луки, до річки i, у свою чергу, організовувати працю дітей на природі, збирати колекції (камінців, пір’їнок, квітів та ін.), виготовляти та спостерігати за паперовими вітрячками тощо. Також вона пропонувала дітям вирізування 3 паперу різні рослини, тварини у поєднанні 3 іншими матеріалами (Русова, 1997, с. 120).

Працю дитини не доцільно обмежувати лише папером, картоном, глиною, тобто «...матеріалом для ручної праці і графічного мистецтва може бути всебічне наведення місцевої історії, місцевої природи і рідної орнаментики» (Русова, 1993, с. 115). У дитячому садку необхідно використовувати той національний матеріал, який поширений у певній місцевості і яким люди користувались для своїх потреб: крейду, глину, кору дерев, кам'яну сіль, мох, льон, коноплю, все, що пов'язане 3 хліборобством. Такий підхід до використання різних матеріалів для занять з ручної праці свідчить про врахування автором регіонального підходу у виховній роботі, без якого неможливо прищепити дитині національні риси особистості, виховати патріотичні почуття, сприяти укріпленню духовної єдності поколінь.

Улюбленим заняттям дітей, як вказує С. Русова, є плетіння та вишивка 3 вовни, ниток, соломи, лози. Малюки виплітають торбинки, кошики, гамаки для себе i товаришів. До такого виду робіт залучаються не лише дівчатка, а й хлопці. Вишиваючи серветку, хустку для ляльки, рушничок, діти вчаться відшукувати гармонію у кольорах, вигадувати комбінацію орнаментів. Звісно, у таких роботах широко використовують український орнамент, який у дитячих руках набуває нових варіацій, і все це, безумовно, сприяє не лише розвитку художнього смаку, а й вихованню патріотичних почуттів, шанобливого ставлення до національної культури, працелюбності.

Аналіз педагогічної спадщини Софії Русової дозволяє з'ясувати, що вона грунтовно досліджувала зарубіжний досвід та наукові праці відомих вчених, серед яких були і педагогічні погляди Ф. Фребеля, що мали неабиякий вплив на українське дошкілля у ті роки. Просвітителька звертала увагу вихователів на необхідність критичного ставлення до використання методики Ф. Фребеля при проведенні занять 3 ручної праці, пристосовуючи їх до нових історичних умов. На думку автора, не завжди слід використовувати на заняттях «метод так званої центральної ідеї», коли вихователь проводить бесіду, гру і обов'язково ручну працю на певну, заздалегідь намічену тему. Педагог доводить, що виготовлення однакових робіт всіма дітьми не сприяє розвитку особистості: «Тут нема місця ні ініціативі, ні творчій фантазії, ні самодіяльності дітей..., а наслідком праці виступають одноманітні предмети, дітям абсолютно не потрібні» (Русова, 1997, 1, с. 97). Ці слушні поради просвітительки враховують сучасні вихователі в закладах дошкільної освіти. Приміром, 3 метою активізації розумової діяльності та творчості дітей на заняттях з ручної праці, що зараз має назву «художня праця», їм пропонують декілька зразків виробів, різноманітний за кольором, фактурою матеріал, дають можливість самостійно обрати спосіб виготовлення виробу. Такий педагогічний підхід стимулює самостійність, художню творчість дошкільників, спонукає до виготовлення нових і нестандартних робіт. Організовуючи роботу 3 художньої праці, в сучасних закладах дошкільної освіти вихователі проводять 3 дітьми 
і такі види занять, як заняття за умовами та за задумом, в процесі яких пропонують дітям певну умову для створення виробів, та надають їм значну самостійність при доборі матеріалів, інструментів, засобів поєднання частин виробу тощо. Наприклад, дітям пропонують виготовити подарунки для батьків до Різдвяних або Великодніх свят, і кожна дитина самостійно продумує, який виріб вона буде створювати, в якій послідовності, що для цього потрібно. Використання такого виду занять сприяє вияву дитячої уяви, ініціативи, самостійності, конструктивних та творчих здібностей, формує корисні практичні навички, виховує моральні якості особистості.

Висновки і перспективи подальших розвідок. Викладене переконує нас в тому, що методичні поради Софії Русової щодо використання ручної праці у вихованні дошкільників вже сьогодні стали надбанням сучасних закладів дошкільної освіти. На заняттях з ручної праці дітям пропонують різні матеріали відповідно до їх вікових особливостей та інтересів. Вихователі знайомлять дошкільників 3 народними ремеслами та виробами народних майстрів: національною вишивкою, витинанками, писанкарством, різьбленням, звертають увагу на їх колорит, особливості виготовлення, оформлення. Відроджуються українські народні традиції та свята, в яких діти беруть активну участь і до яких виготовляють різні прикраси та вироби, використовуючи при цьому елементи національного мистецтва. Вихователі прагнуть якнайширше використовувати ручну працю як важливий засіб виховання, який впливає на особистісне зростання дошкільника: його світогляд, самосвідомість, інтереси, формування таких важливих якостей особистості, як працелюбність, акуратність, ініціативність, творчість, товариська взаємодопомога, воля та багато інших, які стають основою людського життя.

Отже, педагогічні ідеї С. Русової щодо використання ручної праці у вихованні дошкільників заслуговують на подальше вивчення й творче використання в роботі сучасних закладів дошкільної освіти. Теоретичні положення та методичні рекомендації просвітительки не втратили актуальності, a їх впровадження сприятиме удосконаленню національної дошкільної освіти.

\section{СПИСОК ВИКОРИСТАНИХ ДЖЕРЕЛ}

Русова, С. (1997). Вибрані педагогічні твори: книга 1 / за ред. С. І. Коваленко; упоряд., прим. Є.І.Коваленко, І.М.Пінчук. Київ: Либідь, с. 272.

Русова, С. (1997). Вибрані педагогічні твори: книга 2 / за ред. С. І. Коваленко; упоряд., прим. Є.І.Коваленко, І.М.Пінчук. Київ: Либідь, с. 320.

Русова, С.(1993). Теорія і практика дошкільного виховання. Львів - Краків Париж: Просвіта, с. 127.

\section{REFERENCES}

Rusova, S. (1997). Vybrani pedahohichni tvory: knyha 1 [Selecred Pedagogical Works: Book 1]. red. Ye.I.Kovalenko; uporiad., prym. Ye.I.Kovalenko, I.M.Pinchuk. Kyiv: Lybid. S. 272.

Rusova, S. (1997). Vybrani pedahohichni tvory: knyha 2 [Selected Pedagogical Works: Book 2]. red. Ye.I.Kovalenko; uporiad., prym. Ye.I.Kovalenko, I.M.Pinchuk. Kyiv: Lybid. S. 320.

Rusova, S.(1993). Teoriia i praktyka doshkilnoho vykhovannia [Theory and Practice of Preschool Education]. Lviv - Krakiv - Paryzh: Prosvita. S. 127. 


\title{
CREATIVE IMPLEMENTATION OF S. RUSOVA'S IDEAS IN THE PROCESS OF USING MANUAL LABOR IN THE WORK OF PRESCHOOL EDUCATION INSTITUTIONS
}

\author{
Tetiana Yeskova \\ Candidate of Pedagogical Sciences, Associate Professor \\ Associate Professor at the Department of Pre-School Education \\ Berdiansk State Pedagogical University, \\ Berdiansk, Ukraine \\ ORCID: 0000-0003-4666-6871, \\ e-mail: tani4kaeskova@gmail.com
}

\begin{abstract}
Radical restructuring of education in Ukraine, which is the most important component of social and economic transformations of modern society, encourages scientists to develop advanced theoretical and methodological models of labor education in preschool children on the basis of achievements of pedagogical theory and practice of previous years. In this context, historical experience of the problems of using manual labor in the education of preschool children, and pedagogical heritage of Sofia Rusova in particular is essential. In Rusova's methodical works it has been ascertained that one of the important factors in early childhood education is manual labor, which affects the versatile development of a personality. Thanks to her such important personality traits as diligence, punctuality, initiative, creativity, sociable mutual support, will and many others form which are the basis in human life. The teacher emphasized that labor education should start in the family, because a child gets the first labor skills in it. From the point of Rusova's view, the content of child labor should correspond not only to the age and individual characteristics of the child, but also to the time of year. That's why for each season she proposed the content of work and provided specific advice for teachers on child labor organization. To Rusova's mind in order the manual labor to be good for physical and mental development of children, it had to meet certain requirements to be interesting for children. The distinguished educator emphasized the need to combine learning with practical activity and noted that by constantly developing a hand that is one of the best tools for expression and that enables the child to understand the whole material world as much as possible, we enable the child to acquire new information more firmly.

The ideas of using manual labor, which were highlighted in the Rusova's works, were important for the creation of program methodical documents, organization of educational process in the following periods of the national system of preschool education development and can be creatively used by preschool teachers in the modern preschool educational institutions for development of effective educational technologies.
\end{abstract}

Keywords: manual labor, labor education, industriousness, manual labor classes.

Стаття надійшла до редакиї 08.10.2019 р 